JURNAL KETAHANAN NASIONAL

Vol. 24, No. 3, Desember 2018, Hal 306-325

DOI:http://dx.doi.org/ 10.22146/jkn.38349

ISSN:0853-9340(Print), ISSN:2527-9688(Online)

Online sejak 28 Desember 2015 di :http://jurnal.ugm.ac.id/JKN

VOLUME 24

No. 3, Desember 2018

Halaman 306-325

\title{
Implikasi Peran Pemuda Dalam Penanggulangan Bencana Kebakaran Hutan Dan Lahan Terhadap Ketahanan Wilayah (Studi Pada Pemuda Komunitas Elite Armada Rimba Sriwijaya, Kabupaten Ogan Ilir, Sumatra Selatan)
}

\author{
Sundari Utami \\ Program Studi Ketahanan Nasional UGM \\ email: sundarii.utami@gmail.com \\ Armaidy Armawi \\ Fakultas Filsafat Universitas Gadjah Mada \\ email: armaidy@ugm.ac.id(official email) \\ Danang Sri Hadmoko \\ Fakultas Geografi Universitas Gadjah Mada \\ email: danangsrihadmoko@ugm.ac.id
}

\begin{abstract}
This theses analyzed the role of youth in handling forest and land fire disasters on the Ogan Ilirresilience.

The research method used qualitative with descriptive analysi. .Data collection technique in this study used observation, interview, and documentation. Then, data analysis technique in this research was data reduction, data categories, data presentation, and conclusions.

The result showed that the roles of youth in overcome the forest and land fires disaster had three stages. First, prevention, done by socialization to students and coaching on self, people, and environment. Second, counter measure, carried out by monitoring, keeping communication, and firefighting. Then the third, after disaster, there was no disaster so the things done by this community. The role of youth, represented by Elite Arari Community had implications to all aspects of regional resilience; geographically, it emerged the awareness and concern to environment; on the demographical aspect it changed the community mindset, created conducive political situation, kept the economic stability, maintained the social condition of the society and prevented conflicts, and rised up the sense of security for the people in Ogan Ilir region.
\end{abstract}

Keywords: Youth Role, Elite Arari Community, Disaster Management, Forest and Land Fire Disaster, Regional Resilience

\footnotetext{
ABSTRAK

Penelitian ini menganalisis implikasi peran pemuda Komunitas Elite Arari dalam penanggulangan bencana kebakaran hutan dan lahan terhadap ketahanan wilayah di Ogan Ilir.

Penelitian ini menggunakan metode deskriptif kualitatif. Teknik pengumpulan data dilakukan empat tahap yaitu observasi, wawancara, dokumentasi, dan kepustakaan. Teknik analisis data dalam penelitian ini, yakni reduksi data, kategori data, penyajian data, dan penarikan kesimpulan.
} 
Sundari Utami, Armaidy Armawi, Danang Sri Hadmoko -- Implikasi Peran Pemuda Dalam Penanggulangan Bencana Kebakaran Hutan Dan Lahan Terhadap Ketahanan Wilayah (Studi Pada Pemuda Komunitas Elite Armada Rimba Sriwijaya, Kabupaten Ogan Ilir, Sumatra Selatan)

Hasil penelitian menunjukkan bahwa peran pemuda dalam menanggulangi bencana kebakaran terbagi menjadi tiga tahapan. Pertama, tahap pra bencana, dilakukan dengan sosialisasi terhadap pelajar serta melakukan pembinaan terhadap diri sendiri, sesama, dan lingkungan. Kedua, pada saat bencana peran dilakukan dalam bentuk kegiatan pemantauan dan komunikasi serta pemadaman kebakaran hutan dan lahan. Ketiga, tahap pasca bencana tidak terdapat hal yang dilakukan. Peran pemuda dari Komunitas Elite Arari berimplikasi pada seluruh aspek ketahanan wilayah, pada aspek geografi mampu menumbuhkan kesadaran dan kepedulian terhadap lingkungan, pada aspek demografi dengan merubah pola pikir masyarakat, menciptakan kondisi situasi politik yang kondusif, mewujudkan kesejahteraan masyarakat melalui kegiatan pereonomian yang kondusif, menjaga kondisi sosial masyarakat agat tidak terjadi konflik vertikal dan horizontal, serta mampu menciptakan rasa aman bagi masyarakat di wilayah Ogan Ilir.

Kata Kunci : Peran Pemuda, Komunitas Elite Arari, Penanggulangan Bencana, Kebakaran Hutan dan Lahan, Ketahanan Wilayah.

\section{PENGANTAR}

Ketahanan wilayah merupakan awal terwujudnya ketahanan nasional suatu negara. Bencana menjadi salah satu hal yang mempengaruhi ketahanan wilayah, terdapat tiga jenis bencana menurut Undang-Undang No. 24 Tahun 2007, yaitu bencana alam, bencana non-alam, dan bencana sosial. Selanjutnya, Permen Lingkungan Hidup No. 32 Tahun 2016 Tentang Pengendalian Hutan menjelaskan bahwa bencana kebakaran hutan dan lahan merupakan bencana alam berupa peristiwa terbakarnya hutan dan atau lahan baik secara alami maupun akibat aktivitas manusia sehingga mengakibatkan kerusakan lingkungan yang menimbulkan kerugian ekologi, ekonomi, sosial budaya dan politik.

Di Indonesia bencana karhutla sudah terjadi sejak lama, pada tahun 1997 bencana karhutla di Indonesia mulai berdampak pada negara tetangga dengan kabut asap yang ditimbulkan sehingga sangat mengganggu dan merugikan Indonesia maupun negara tetangga (Glover dan Jessup, 2002). Kebakaran hutan dan lahan mengakibatkan kerugian pada aspek ekonomi, pertanian, lingkungan hidup, kehutanan, industri, kesehatan, pendidikan, perdagangan, dan juga tingginya biaya yang dikeluarkan guna pemadaman kebakaran (The World Bank, 2016).
Kebakaran hutan dan lahan di Indonesia terjadi dan menyebar luas di berbagai provinsi terutama di wilayah Kalimantan Barat, Kalimantan Timur, Kalimantan Utara, Kalimantan Tengah, Sumatera Selatan, Jambi, dan Riau. Pada tahun 2014 dari seluruh hotspot rawan terbakar yang ada di Indonesia, 20\% terdapat di Provinsi Sumatera Selatan (Bioclime, 2015). Bencana kebakaran hutan dan lahan yang terjadi di Sumatera Selatan menyebar di beberapa kabupaten, salah satu kabupaten yang memiliki titik rawan cukup banyak adalah Kabupaten Ogan Ilir. Kabupaten Ogan Ilir tersebut memiliki tingkat kerawanan bencana kebakaran cukup tinggi dibanding dengan daerah lainnya yakni terdapat 39.247 hotspot rawan, 135.213 dengan tingkat kerawanan sedang, dan 52.113 dengan tingkat kerawanan tinggi (Bioclime, 2015:31).

Pemerintah Provinsi Sumatera Selatan melakukan penanggulangan bencana melalui Badan Penanggulangan Bencana Daerah (BPBD) Kabupaten Ogan Ilir bekerjasama dengan pemerintah pusat dan pihak terkait, selain itu pemerintah juga terus mendorong peran serta dari seluruh lapisan masyarakat sebagai salah satu upaya untuk mencegah dan menanggulangi bencana kebakaran hutan dan lahan melalui sosialisasi dan himbauan yang diberikan kepada masyarakat terkait bahaya 
kebakaran hutan dan lahan, pencegahan, dan cara penanggulangannya. Penanggulangan bencana kebakaran hutan dan lahan tidak dapat ditanggulangi tanpa adanya peran serta dari masyarakat karena bencana ini terjadi pada wilayah yang cukup luas dan titik api yang menyebar.

Pengurangan resiko bencana kebakaran hutan dan lahan berbasis komunitas masyarakat sangat diperlukan dikarenakan wilayah geografis Indonesia yang luas dan tersebar di 17.504 ribu pulau, maka akan lebih efektif bila kapasitas penanggulangan kebakaran diperkuat termasuk pada tingkat komunitas guna meningkatkan kerelawanan pada semua tataran dan lapisan masyarakat untuk turut serta menanggulangi bencana kebakaran lahan (Triutomo, 2013:5). Di Kabupaten Ogan Ilir terdapat suatu komunitas pecinta alam yang memiliki kepedulian terhadap adanya ancaman bencana kebakaran hutan dan lahan di wilayah Ogan Ilir, komunitas tersebut bernama Komunitas Pecinta Alam Elite Armada Rimba Sriwijaya (Elite Arari).

Komunitas Elite Arari merupakan komunitas pecinta alam yang anggotanya terdiri dari para pemuda yang peduli terhadap lingkungan di wilayah Ogan Ilir. Komunitas ini menyadari adanya kerentanan wilayah Ogan Ilir terhadap bencana kebakaran hutan dan lahan terutama pada saat musim kemarau. Hal tersebut menumbuhkan minat Komunitas Elite Arari untuk turut serta terjun secara langsung membantu petugas BPBD Kabupaten Ogan Ilir dalam menanggulangi bencana kebakaran hutan dan lahan terutama yang terjadi di wilayah Kabupaten Ogan Ilir. Minat pemuda di Kabupaten Ogan Ilir untuk turut serta menanggulangi bencana kebakaran hutan dan lahan masih sangat rendah, sehingga penanggulangan bencana kebakaran hutan dan lahan hanya dibebankan pada pihak BPBD Ogan Ilir dan pihak terkait seperti TNI, POLRI, dan pihak lainnya.

Kehadiran Komunitas Elite Arari dalam kegiatan penanggulangan bencana kebakaran hutan dan lahan mampu memperkuat ketahanan wilayah di Kabupaten Ogan Ilir terutama dalam menghadapi ancaman bencana. Cakupan daerah yang luas mencapai 226.653 Ha serta kondisi medan yang sulit tentu membutuhkan peran serta dari seluruh masyarakat termasuk para pemuda yang tergabung dalam Komunitas Elite Arari dalam menanggulangi bencana tersebut. Peran yang dianalisis pada penelitian ini hak dan kewajiban sesuai dengan kedudukan yang dilakukan oleh Komunitas Elita Arari dalam kegiatan penanggulangan bencana kebakaran hutan dan lahan di Kabupaten Ogan Ilir (Soekanto, 2015:211).

Penanggulangan bencana menurut PP No. 21 Tahun 2008 Tentang Penyelenggaraan Penanggulangan Bencana terbagi menjadi 3 (tiga) tahapan kegiatan, yaitu pertama, pra bencana, meliputi keadaan meliputi dua keadaan yaitu situasi tidak terjadi bencana dan situasi terdapat potensi terjadi bencana. Kedua, saat bencana meliputi pengkajian secara cepat dan tepat terhadap lokasi, kerusakan, dan sumber daya, penentuan status keadaan darurat bencana, penyelamatan dan evakuasi masyarakat terkena bencana, pemenuhan kebutuhan dasar, perlindungan, dan pemulihan sarana prasarana dengan segera. Ketiga, pasca bencana, meliputi rehabilitasi dan rekonstruksi.

Peran pemuda merupakan elemen masyarakat yang penting dalam kegiatan pengurangan resiko bencana adalah para pemuda, dinilai sangat efektif dalam kegiatan pengurangan resiko bencana karena para 
Sundari Utami, Armaidy Armawi, Danang Sri Hadmoko -- Implikasi Peran Pemuda Dalam Penanggulangan Bencana Kebakaran Hutan Dan Lahan Terhadap Ketahanan Wilayah (Studi Pada Pemuda Komunitas Elite Armada Rimba Sriwijaya, Kabupaten Ogan Ilir, Sumatra Selatan)

pemuda dinilai memiliki semangat yang tinggi sehingga dapat melakukan pencegahanpencegahan dan penanggulangan sesuai dengan hak dan tanggungjawabnya. Para pemuda Komunitas Elite Arari ini dapat menjadi perintis yang menggerakkan masyarakat lainnya sehingga akan menjadi lebih tangguh saat menghadapi bencana (Pradikta, dkk, 2018:263).

Peran para pemuda anggota dari Komunitas Elite Arari memiliki implikasi terhadap ketahanan wilayah di Ogan Ilir dikarenakan bencana kebakaran hutan dan lahan terjadi setiap tahun pada lingkup wilayah yang luas dan titik api yang tersebar di wilayah Ogan Ilir. Permasalahan yang dihadapi oleh pihak BPBD Ogan Ilir ialah keterbatasan anggota satgas yang hanya berjumlah 25 orang, meskipun mendapatkan bantuan dari pihak lain namun ketika bencana kebakaran meluas maka sulit untuk ditanggulangi.

Konsep ketahanan wilayah berkaitan dengan ketangguhan dan keuletan suatu wilayah dalam menghadapi berbagai hambatan dan tantangan yang menimbulkan dampak negatif bagi suatu wilayah. Ketahanan wilayah merupakan rangkaian dari delapan aspek ketahanan nasional dalam lingkup wilayah yang dikenal dengan Astagatra, terdiri dari Trigatra meliputi aspek geografi, kekayaan alam, dan penduduk serta Pancagatra meliputi aspek ideologi, politik, sosial budaya, ekonomi, dan pertahanan keamanan (Lemhannas, 1997).

Alfaqi dkk (2017) dalam kajiannya mengemukakan bahwa ketahanan wilayah merupakan bentuk mikro dari ketahanan nasional, dimana setiap aspek pada ketahanan wilayah akan memiliki dampak terhadap ketahanan nasional sebagai bentuk ketahanan yang sebenarnya. Bencana kebakaran hutan dan lahan yang terjadi menimbulkan banyak permasalahan yang terjadi di masyarakat. Konflik menjadi salah satu akibat yang saling muncul pada saat terjadi kebakaran hutan dan lahan, selain itu juga munculnya berbagai masalah kesehatan yang ditimbulkan akibat memburuknya kualitas udara karena asap yang ditimbulkan dari terbakarnya hutan dan lahan. Ketahanan wilayah menjadi salah satu aspek penting dalam mewujudkan ketahanan nasional negara, sehingga stabilitas ketahanan wilayah sangat diperlukan.

Berdasarkan latar belakang di atas, maka dirumuskan tujuan dari penelitian ini adalah untuk menganalisis implikasi dari peran pemuda dalam penanggulangan bencana kebakaran hutan dan lahan terhadap ketahanan wilayah di Kabupaten Ogan Ilir Provinsi Sumatera Selatan. Penelitian ini bersifat deskriptif dengan menggunakan pendekatan kualitatif, deskripsi menggambarkan atau menceritakan secara rinci dan akurat tentang hal-hal yang dilihat, dialami dan di dengar oleh peneliti pada saat melakukan kegiatan penelitian. Berkaitan dengan hal tersebut, maka dalam penelitian ini peneliti mendeskripsikan tentang implikasi dari bentuk-bentuk peran pemuda yang telah dilakukan oleh Komunitas Elite Arari dalam penanggulangan bencana kebakaran lahan ketahanan wilayah di Ogan Ilir.

Peneliti menggunakan beberapa teori sebagai pedoman dalam melakukan penelitian dan juga untuk mempermudah proses analisis data. Beberapa teori yang digunakan yaitu teori peran, teori pemuda, teori bencana, dan teori ketahanan wilayah.

Peran menurut Soekanto (2015) merupakan wujud dari pelaksanaan hak dan kewajiban seseorang sesuai dengan kedudukan yang dimiliki. Peran juga berkaitan dengan aktivitas keterlibatan atau partisipasi 
baik secara langsung maupun tidak langsung, dan peran merupakan tindakan dan tingkah laku berpola yang memiliki status sosial. Pemuda menurut Undang-Undang No. 40 Tahun 2009 tentang Kepemudaan pada Pasal 1 Ayat 1 disebutkan bahwa pemuda adalah warga negara Indonesia yang sedang dalam masa pertumbuhan dan perkembangan usia 16 (enam belas) sampai dengan 30 (tiga puluh) tahun.

Menurut Kollek (2013) bencana merupakan serangkaian peristiwa atau kejadian yang menimbulkan korban jiwa, kerusakan atau kerugian infrastruktur, pelayanan umum, dan kehidupan masyarakat serta berada di luar kapasitas normal dari masyarakat untuk mengatasinya sehingga membutuhkan bantuan dari pihak lain. Sedangkan menurut Undang-Undang No.24 Tahun 2007 tentang Penanggulangan Bencana dijelaskan bahwa adalah peristiwa atau rangkaian peistiwa yang mengancam dan mengganggu kehidupan dan penghidupan masyarakat yang disebabkan baik oleh faktor alam dan atau non alam maupun faktor manusia sehingga menimbulkan korban jiwa, kerusakan lingkungan, kerugian harta benda, dan dampak psikologis.

Ketahanan wilayah yang merupakan bentuk mikro dari ketahanan nasional memiliki beberapa aspek yang menjadi indikator terwujudnya ketahanan suatu wilayah. Aspek tersebut berupa Astagatra, terbagi menjadi dua yaitu Trigatra dan Pancagatra. Trigatra terdiri dari aspek geografi, kekayaan alam, dan penduduk. Pancagatra terdiri dari aspek ideologi, politik, sosial budaya, ekonomi, dan pertahanan keamanan (Lemhannas, 1997).

Pengumpulan data dalam penelitian ini dilakukan dengan menggunakan observasi, wawancara, dokumentasi, dan studi kepustakaan. Sedangkan teknis analisis data pada penelitian ini dilakukan dengan reduksi data, penyajian data, dan pengambilan kesimpulan. Penelitian ini dilakukan di Kabupaten Ogan Ilir Provinsi Sumatera Selatan dikarenakan lokasi ini merupakan lokasi yang memiliki hotspot cukup tinggi dan mengalami bencana kebakaran hutan dan lahan setiap tahunnya.

\section{PEMBAHASAN}

\section{Profil Kabupaten Ogan Ilir}

Kabupaten Ogan Ilir merupakan salah satu kabupaten yang terdapat di Provinsi Sumatera Selatan. Sebelumnya Kabupaten Ogan Ilir (OI) merupakan bagian dari Kabupaten Ogan Komering Ilir (OKI) yang kemudian mengalami pemekaran wilayah dan disahkan sebagai kabupaten pada 18 Desember 2003. Kabupaten Ogan Ilir terletak pada jalur lintas Sumatera yang berarti daerah tersebut memiliki nilai strategis karena dilalui oleh jalur darat yang menghubungan antar provinsi di Pulau Sumatera. Ogan Ilir berbatasan langsung dengan Ibukota Provinsi Sumatera Selatan yaitu Palembang dan berjarak sekitar $35 \mathrm{KM}$, serta berbatasan dengan dua kabupaten lainnya yaitu Kabupaten Ogan Komering Ilir dan Kabupaten Muara Enim. Kabupaten Ogan Ilir terdiri dari 16 Kecamatan, 14 Kelurahan, dan 224 Desa (Ogan Ilir Dalam Angka, 2017).

Secara geografis Kabupaten Ogan Ilir terletak di antara $2^{\circ} 55^{\prime}$ sampai $3^{\circ} 15^{\prime}$ LS di antara $104^{\circ} 20^{\prime}$ BT sampai $104^{\circ} 48^{\prime}$ BT. Bagian sebelah utara berbatasan dengan Kabupaten Banyuasin dan juga Palembang, sebelah selatan berbatasan dengan Kabupaten OKU, sebelah timur berbatasan dengan Kabupaten OKU Timur, sedangkan bagian barat berbatasan dengan Kabupaten Muara Enim. Kabupaten OI memiliki luas wilayah 2.666,07 $\mathrm{Km}^{2}$ atau $266.607 \mathrm{Ha}$, memiliki 
Sundari Utami, Armaidy Armawi, Danang Sri Hadmoko -- Implikasi Peran Pemuda Dalam Penanggulangan Bencana Kebakaran Hutan Dan Lahan Terhadap Ketahanan Wilayah (Studi Pada Pemuda Komunitas Elite Armada Rimba Sriwijaya, Kabupaten Ogan Ilir, Sumatra Selatan)

Gambar 1

Peta Lokasi Penelitian

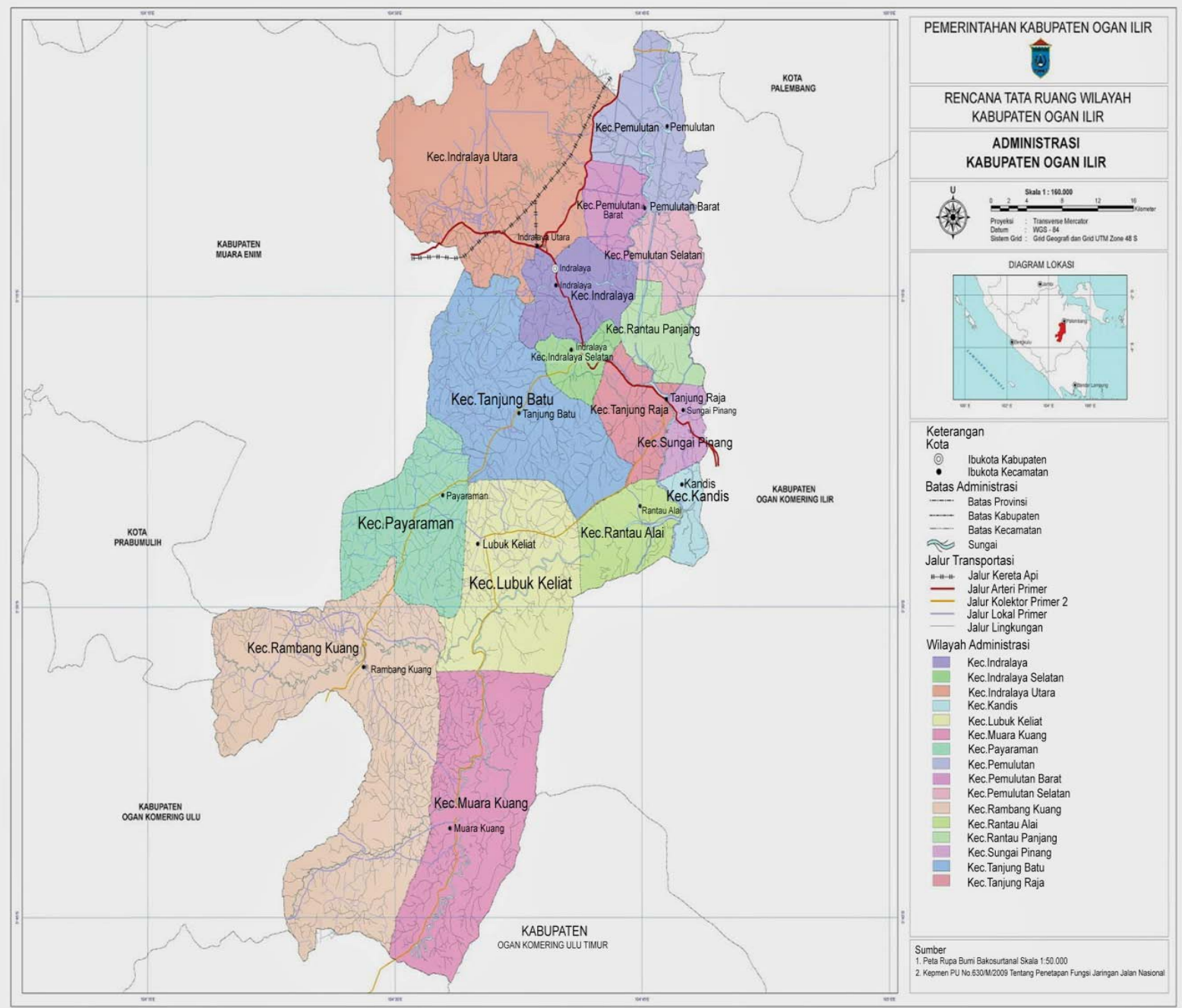

Sumber : Dokumentasi BPBD Ogan Ilir, 2017

ketinggian tempat rata-rata $8 m d p l$ dengan suhu harian berkisar antara $22^{\circ} \mathrm{C}$ hingga $34^{\circ} \mathrm{C}$. Curah hujan rata-rata berkisar antara $2.600 \mathrm{~mm}$ hingga $3.500 \mathrm{~mm}$, dan jumlah hari hujan 112 hari per tahun (gambar 1) (Ogan Ilir Dalam Angka, 2017).

Kondisi demografis terkait dengan komposisi penduduk, penduduk di Ogan Ilir pada tahun 2015 tercatat sejumlah 409.171 jiwa dan kemudian meningkat pada tahun 2016 menjadi 414.504 jiwa. Sedangkan kelompok umur yang termasuk dalam kategori pemuda di Ogan Ilir mencapai 75.714 jiwa Jumlah penduduk yang meningkat setiap tahunnya sedangkan wilayah yang terbatas mengakibatkan konversi lahan dari lahan yang awalnya berupa hutan dan rawa kemudian berubah menjadi pemukiman dan perusahaan-perusahaan yang terus berkembang setiap tahunnya. Kepadatan penduduk yang awalnya 153,47 jiwa $/ \mathrm{km}^{2}$ pada tahun 2015 meningkat menjadi 155,47 jiwa/ $\mathrm{km}^{2}$ pada tahun 2016 atau terdapat 155 orang yang mendiami wilayah setiap kilometer persegi (Ogan Ilir Dalam Angka, 2017).

Kondisi geografis wilayah Ogan Ilir terdiri dari sebagaian besar rawa yang berisi 
rumput dan semak belukar, dan sebagian dari rawa tersebut juga merupakan lahan gambut. Selain itu maraknya pembukaan perkebunan kelapa sawit juga turut mempengaruhi, pembukaan lahan dengan cara membakar menjadi salah satu faktor terjadinya bencana kebakaran hutan dan lahan.

\section{Profil Komunitas Pecinta Alam Elite Armada Rimba Sriwijaya (Elite Arari)}

Komunitas Elite Armada Rimba Sriwijaya (Elite Arari) merupakan sebuah komunitas pecinta alam yang terdapat di wilayah Ogan Ilir Provinsi Sumatera Selatan, memiliki sekretariat di Kelurahan Timbangan tidak jauh dari kampus Universitas Sriwijaya tepatnya di Jalan Prabumulih-Palembang Komplek Ria Mandala. Elite Arari berawal dari adanya sekumpulan pemuda yang sering melakukan kegiatan bersama serta memiliki minat dan hobi yang sama yang kemudian merasa sejalan dan memiliki visi yang sama. Pada saat berkumpul bersama para pemuda tersebut saling berbagi cerita, pengalaman, dan pemikiran serta melakukan kegiatankegiatan yang berbau alam bersama-sama seperti dengan mendaki gunung bersama, melakukan pemungutan sampah di bukit lokasi camping dan lain sebagainya. Hal tersebut dilakukan atas dasar keprihatinan para pemuda terhadap kondisi lingkungan di Sumatera Selatan umumnya dan di Kabupaten Ogan Ilir khususnya.

Para pemuda tersebut memutuskan untuk membuat suatu komunitas pecinta alam agar dapat memberikan dampak positif yang lebih luas bagi masyarakat. Kemudian para pemuda tersebut mulai menyusun draft organisasi, AD/ ART, atribut organisasi, program kerja, visi misi, dan juga struktur organisasi. Selanjutnya pada tangga 11 November 2011 setelah semua berkas dan draft siap maka komunitas tersebut diresmikan menjadi Elite Arari dengan ketua umum Ases Robetya. Saat ini Komunitas Elite Arari memasuki usia tahun ke-8, ikatan yang kuat antar anggota menjadikan kekuatan tersendiri bagi komunitas ini untuk terus eksis dalam menjalankan apa yang menjadi tujuan dari organisasi mereka.

Sampai saat ini komunitas Elite Arari memiliki 29 anggota. Pada awal berjalannya komunitas tersebut masih banyak terdapat keterbatasan dalam menjalankan program kerja yang telah dirancang, namun hal tersebut tidak menghalangi para pemuda tersebut untuk terus bekerja demi mewujudkan kelestarian alam. Di Ogan Ilir sebenarnya terdapat beberapa komunitas yang berorientasi terkait kepecintaan alam namun sampai dengan saat ini hanya satu komunitas pecinta alam yang terdaftar secara resmi di Kesbangpol Kabupaten Ogan Ilir yakni KPA Elite Arari, seperti yang dikemukakan oleh Ayu Lestari :

"Sebenarnya di Ogan Ilir sendiriada banyak
berdiri KPA, namun baru EliteArari yang
secara resmi telah terdaftar di Kesbangpol.
Selain itu juga Elite Arari merupakan
satu-satunya organisasi kepemudaan
yang memiliki fokus lingkungan yang
telah memiliki akte notaris sehingga Elite
Arari merupakan komunitas yang memiliki
kedudukan yang legal” (wawancara dengan
Ayu Lestari, 17 Januari 2018).

Elite Arari senantiasa melakukan kegiatan-kegiatan yang berkaitan dengan alam seperti halnya melakukan kegiatan penanaman pohon, melakukan sosialisasi daur ulang sampah, daur ulang kertas, penyaringan air dan lain sebagainya. Elite Arari juga memberikan perhatian khusus terhadap permasalahan lingkungan di Ogan Ilir, salah 
Sundari Utami, Armaidy Armawi, Danang Sri Hadmoko -- Implikasi Peran Pemuda Dalam Penanggulangan Bencana Kebakaran Hutan Dan Lahan Terhadap Ketahanan Wilayah (Studi Pada Pemuda Komunitas Elite Armada Rimba Sriwijaya, Kabupaten Ogan Ilir, Sumatra Selatan)

Gambar 2

Program EA Go To School

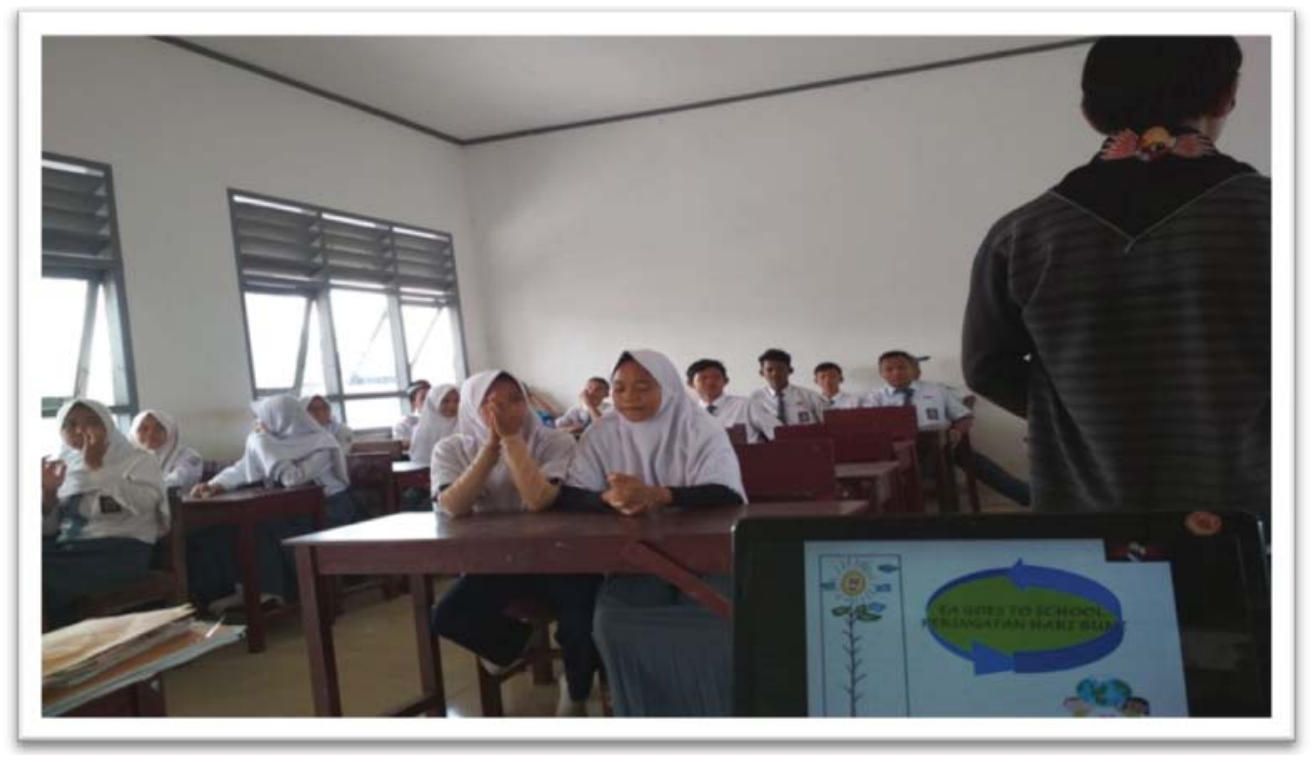

Sumber : Dokumentasi Komunitas Elite Arari, 2018)

satunya terkait bencana kebakaran lahan yang terjadi di Wilayah Ogan Ilir tersebut.

Dibutuhkan kesadaran dan kerjasama untuk menanggulangi bencana kebakaran yang terjadi. Komunitas Elite Arari merupakan sebagian dari para pemuda di Ogan Ilir yang memiliki kepedulian terhadap kondisi lingkungan di wilayahnya dan bersedia membantu pihak BPBD Ogan Ilir dalam menanggulangi bencana kebakaran lahan, dan senantiasa berupaya mencegah terjadinya bencana kebakaran.

\section{Bentuk-Bentuk Peran Pemuda KPA Elite Arari}

Beberapa peran yang dilakukan oleh anggota Komunitas Elite Arari dalam upaya menanggulangi bencana kebakaran hutan dan lahan di Kabupaten Ogan Ilir terbagi menjadi dua tahapan yaitu pada tahap pra bencana dan saat bencana. Sedangkan pada tahap pasca bencana tidak terdapat peran yang dilakukan oleh komunitas ini. Kegiatan yang dilakukan pada tahap pra bencana adalah sebagai berikut.
Pertama, peran yang dilakukan oleh para pemuda anggota komunitas Elite Arari sesuai dengan hak dan kewajibannya pada tahap pra bencana adalah dengan melakukan sosialisasi terhadap pelajar serta melakukan pembinaan diri, sesama, dan lingkungan. Komunitas Elite Arari memiliki hak untuk turut mensosialisasikan pentingnya menjaga lingkungan dan juga memiliki tanggung jawab untuk menjaga dan melestarikan lingkungan di Ogan Ilir sesuai dengan kedudukannya sebagai komunitas pecinta alam di wilayah tersebut. Sosialisasi terhadap pelajar sebagai upaya edukasi terhadap generasi muda, dan upaya pembinaan terhadap diri, sesama, dan lingkungan yang diwujudkan dalam kegiatan kampanye lingkungan, penanaman pohon, dan pembersihan sungai (gambar 2).

Kedua, peran lainnya yang yang dilakukan pada tahap pra bencana adalah pembinaan terhadap diri, sesama, dan lingkungan. Pembinaan terhadap diri ditujukan pada diri anggota masing-masing dengan mengikuti berbagai seminar, workshop dan kegiatan 
lainnya yang dapat menambah wawasan anggota terkait permasalahan lingkungan. Sedangkan kegiatan pembinaan terhadap sesama diwujudkan dengan memberikan pemahaman kepada pihak-pihak lain termasuk orang-orang terdekat di sekitar mereka. Para anggota komunitas meyakini jika mereka tidak menjaga dan menebarkan informasi positif kepada masyarakat yang belum memahami akan arti penting menjaga lingkungan maka kondisi lingkungan di Ogan Ilir akan semakin memburuk, seperti yang dikemukakan oleh Dedi Kurniawan :

"Ketika masyarakat tidak mengetahui dampak dari kebakaran lahan tersebut dan merasa bahwa hal tersebut adalah hal yang lumrah terjadi setiap tahun disaat kemarau maka setiap orang yang tidak mengetahui dampaknya bagi manusia dan kondisi alam yang semakin rusak saat terjadi bencana maka akan bersikap apatis. Bahkan sayapun jika tidak bergabung dengan organisasi yang bertajuk kepecintaan alam ini, mungkin saya juga tidak akan paham akan dampak dari bencana tersebut dan tentu saya akan bersikap apatis. Kami peduli karena kami tahu bahwa alam telah ada sejak kami belum ada sehingga ketika alam itu rusak maka kami yang harus bertanggung jawab, kami juga sadar jika alam mampu bertahan tanpa manusia tetapi manusia pasti tidak akan mempu bertahan tanpa alam"(Wawancara dengan Dedi Kurniawan, 17 Januari 2018).

Kegiatan bina lingkungan diwujudkan dalam kegiatan-kegiatan yang bertujuan untuk menjaga dan melestarikan alam di daerah Ogan Ilir. Para pemuda anggota komunitas Elite Arari biasanya melakukan kegiatan kampanye dan aksi lingkungan, seperti dengan memperingati hari lingkungan seperti hari air dan hari bumi. Selain itu juga membuat acara yang positif seperti melakukan susur sungai sambil membersihkan sampah, daur ulang sampah, penyaringan air, dan melakukan penanaman pohon. Hal-hal demikian dilakukan sebagai bentuk kampenye kepedulian terhadap lingkungan.

Peran pemuda Komunitas Elite Arari selajutnya dilakukan pada tahap saat bencana atau tanggap darurat. Pada tahap ini Komunitas Elite Arari memiliki kewajiban untuk turut serta menanggulangi bencana karhutla yang terjadi sesuai dengan kedudukannya sebagai komunitas pecinta alam dan juga sebagai bagian masyarakat Ogan Ilir, serta memiliki hak untuk ikut memadamkan kebakaran dan mendapatkan fasilitas peralatan yang memadai dari pihak pemerintah. Pemadaman karhutla dilakukan oleh berbagai pihak terkait, di antaranya BNPB, BPBD Kabuapten Ogan Ilir, TNI, para petugas yang diutus oleh perusahaan-perusahaan, dan juga para relawan yang berada di wilayah Ogan Ilir sebagai bentuk upaya menghadapi bencana kebakaran lahan. Sejauh ini peran yang ditunjukkan oleh pihak-pihak tersebut seringkali tidak berjalan maksimal, seperti yang dikemukakan oleh Kepala Staf Satuan Pencegahan dan Kesiapsiagaan BPBD Ogan Ilir Ibu Pipit Oktarina :

"Memang terdapat banyak pihak yang turut serta bersiaga di Posko Api yang telah didirikan, begitu juga dari pihakperusahaanperusahaan biasanya juga mendirikan posko siaga api tapi kebanyak mereka tidak selalu standby di posko tersebut, mungkin hanya terdapat satu atau dua petugas saja yang hadir. Posko menurut saya didirikan hanya sebagai bentuk formalitas tapi tidak benarbenar dilaksanakan. Sehingga ketika terjadi kebakaran memang kami yang menjadi tulang punggung pemadaman, maka dari itu kami bersyukur dengan hadirnya adikadik dari Elite Arari dan pihak lain yang turut membantu" (Wawancara dengan Pipit Oktarina, 23 Januari 2018). 
Sundari Utami, Armaidy Armawi, Danang Sri Hadmoko -- Implikasi Peran Pemuda Dalam Penanggulangan Bencana Kebakaran Hutan Dan Lahan Terhadap Ketahanan Wilayah (Studi Pada Pemuda Komunitas Elite Armada Rimba Sriwijaya, Kabupaten Ogan Ilir, Sumatra Selatan)

Gambar 3

Anggota Komunitas Elite Arari di Posko Siaga Api

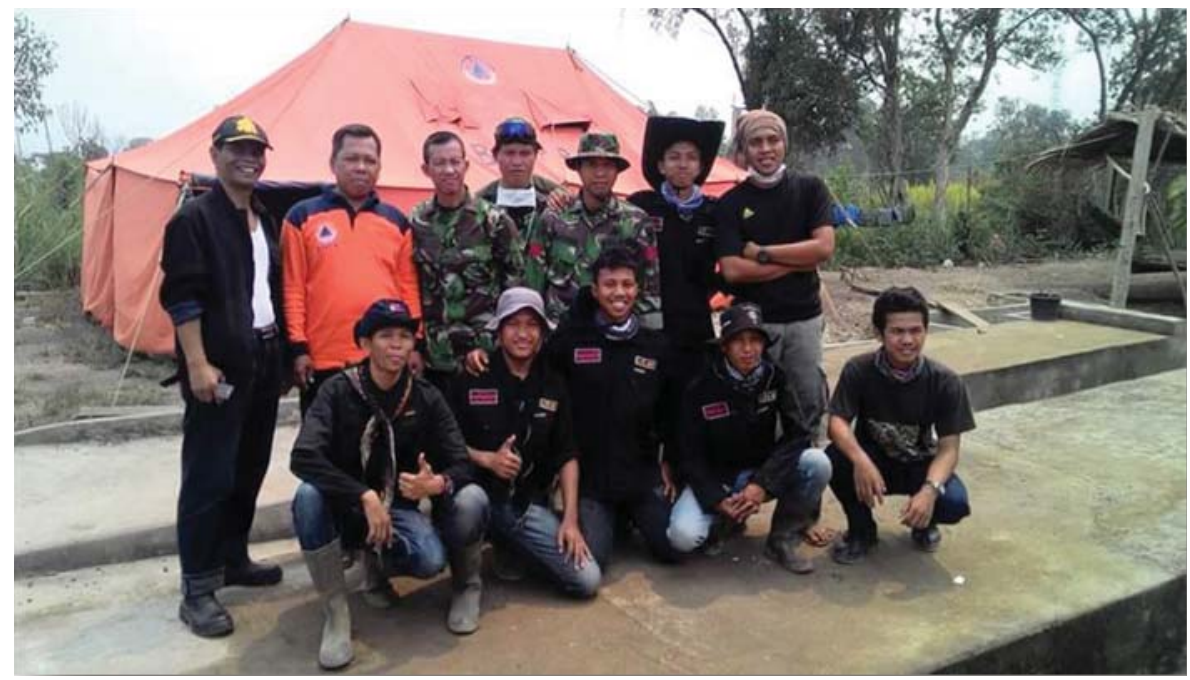

Sumber : Dokumentasi Komunitas Elite Arari, 2017

Upaya yang dilakukan oleh Elite Arari pada saat terjadi bencana karhutla sendiri terbagai menjadi beberapa kegiatan, yang pertama dalam bentuk pemantauan dan komunikasi yang dilakukan antara BPBD, satgas di lapangan, dan anggota komunitas yang tidak berada di lokasi bencana. Kedua, upaya pemadaman kebakaran lahan yang dilakukan di Ogan Ilir lapangan oleh Elite Arari bersama-sama dengan BPBD. Secara lebih lengkap dapat dijelaskan sebagai berikut.

Pertama, pemantauan dan komunikasi. Pada saat memasuki musim kemarau maka pihak BPBD akan melakukan rapat koordinasi antar pihak-pihak yang terkait seperti Perusahaan yang terdapat di wilayah rawa titik api, BPBD Ogan Ilir, BPBD Provinsi, TNI/POLRI, dan juga SKPD terkait. Rapat koordinasi juga dilakukan beberapa kali sampai ditemukan kesepakatan terkait hal-hal yang harus dipersiapkan untuk menghadapi bencana kebakaran yang mengancam, seperti yang disampaikan oleh Pipit Oktarina :

"Dari awal kami sudah mempersiapkan melalui rapat koordinasi dengan semua pihak yang terkait seperti TNI/ Polri, petugas kesehatan, mandala Agni, Perusahaan,Kepala Daerah, dan lintas SKPD. Kami melakaukan rapat koordinasi setidaknya 3 kali untuk salaing sharing untuk mempersiapkan diri sebelum terjadinya bencana. Pertama kali dipimpin oleh Bupati, kedua oleh BPBD Sumsel, dan ketiga dari Komandan Kodim. Kemudian BPBD OI sebagai posko induk, terdapat 3 posko utama yakni di KTM, Parit, dan Arisanjaya. Begitu juga dengan Elite Arari, mereka juga mendapat bagian untuk menjaga posko tersebut" (Wawancara dengan Pipit Oktarina, 23 Januari 2018).

Elite Arari mempunyai peran yang penting dalam hal ini karena anggotanya juga menjadi petugas yang bersiaga di posko bersama BPBD Ogan Ilir, anggota Elite Arari membagi tugas antar anggota komunitas untuk mengatur jadwal jaga di posko api tersebut, jadwal tersebut disusun berdasarkan waktu yang dimiliki oleh anggota. Anggota Elite Arari bersama BPBD yang siaga di posko akan melakukan pemantauan terhadap lahan yang memang memiliki tingkat kerawanan tinggi terhadap potensi terjadinya kebakaran 


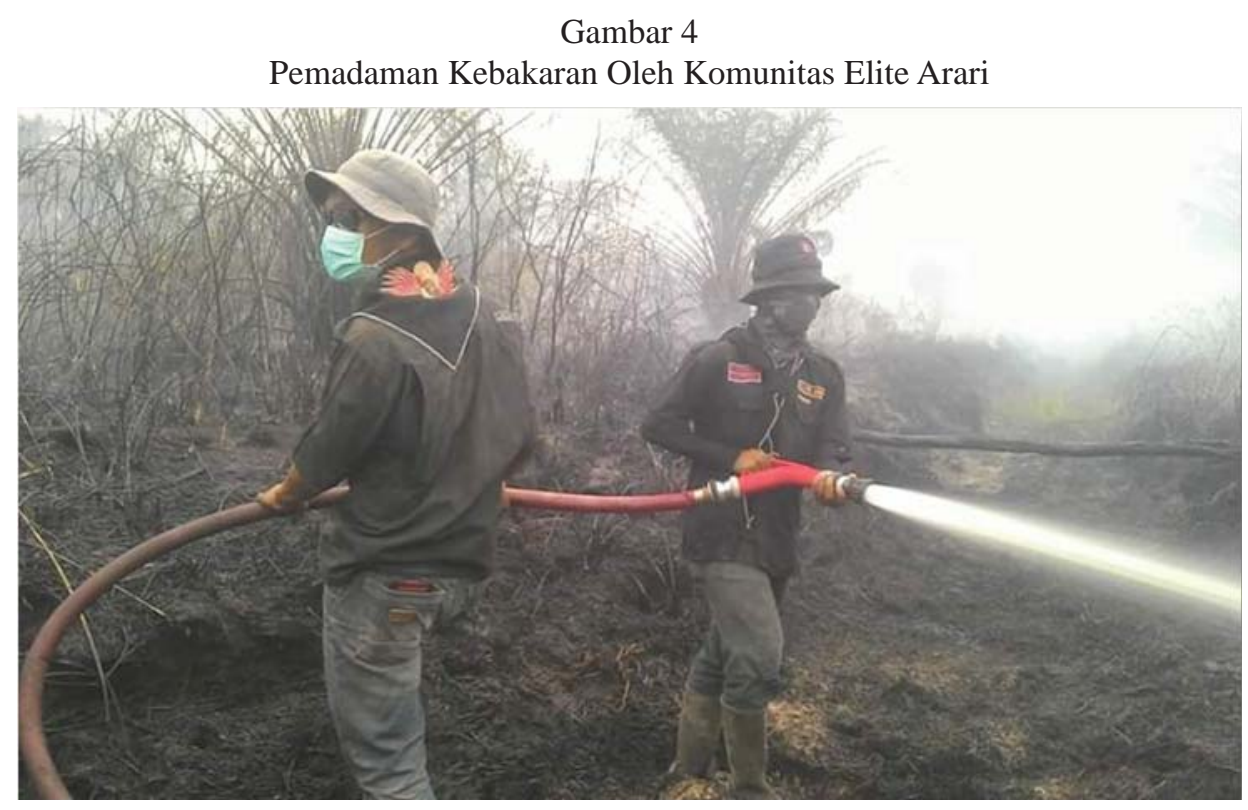

Sumber : Dokumentasi Komunitas Elite Arari, 2017

hutan dan lahan, petugas akan melakukan patroli ke daerah-daerah di sekitar posko untuk mengetahui adanya titik api. Selain petugas yang melakukan patroli lapangan terdapat juga petugas yang berjaga di posko untuk mengantisipasi adanya laporan titik api baik dari masyarakat maupun dari pihak petugas lapangan (gambar 3).

Pemantauan yang dilakukan kemudian dilanjutkan dengan komunikasi, informasi terkait kondisi titik api yang ditemukan di lapangan akan diteruskan ke petugas yang berada di posko. Kemudian petugas yang ada akan mengirimkan peralatan pemadaman berupa mobil pembawa tanki berisi air, mesin penyedot air, dan juga selang, serta peralatan yang diperlukan guna memadamkan api.

Kedua, upaya pemadaman kebakaran hutan dan lahan. Elite Arari senantiasa turut serta dalam kegiatan pemadaman kebakaran hutan dan lahan yang terjadi dengan semaksimal mungkin sesuai kemampuan yang mereka miliki. Dalam proses pemadaman kebakaran lahan memang hanya anggota lelaki saja yang diikutsertakan mengingat akses, medan, dan ancaman yang terjadi saat kebakaran lahan. Hal tersebut mendapat sambutan baik dari pihak BPBD Ogan Ilir yang memang sangat membutuhkan bantuan dari berbagai pihak mengingat luasnya wilayah yang harus diawasi dan ditanggulangi dan juga terbatasnya anggota satgas bencana dari BPBD Kabupaten Ogan Ilir yang hanya berjumlah sekitar 25 orang.

Pihak BPBD memiliki tiga titik fokus utama dalam melakukan pemadaman kebakaran lahan yaitu wilayah yang dekat dengan pemukiman, wilayah yang dilalui jalur pipa gas, dan wilayah yang terekspose serta dekat jalur transportasi. Ketika terjadi kebakaran pada saat bersamaan maka daerah tersebut yang lebih didahulukan. Tugas Komunitas Elite Arari lah yang diberi tanggung jawab untuk memadamkan dan mencegah meluasnya kebakaran lahan di daerah lain yang tidak termasuk tiga titik fokus tersebut dipandu oleh pihak BPBD (gambar 4).

Kerjasama antar pihak terkait sangat dibutuhkan dalam penanggulangan kebakaran, tidak hanya mengandalkan pihak pemerintah 
Sundari Utami, Armaidy Armawi, Danang Sri Hadmoko -- Implikasi Peran Pemuda Dalam Penanggulangan Bencana Kebakaran Hutan Dan Lahan Terhadap Ketahanan Wilayah (Studi Pada Pemuda Komunitas Elite Armada Rimba Sriwijaya, Kabupaten Ogan Ilir, Sumatra Selatan)

tetapi juga peran dari seluruh elemen masyarakat untuk dapat membantu mencegah dan menanggulangi bencana. Hal tersebut hendaknya dilakukan berkesinambungan mengingat wilayah Ogan Ilir memiliki kerentanan tinggi terhadap bencana kebakaran lahan.

\section{Implikasinya Terhadap Ketahanan Wilayah Aspek Geografi}

Komunitas Elite Arari turut meminimalisir kerugian akibat dampak dari bencana kebakaran hutan dan lahan dengan melakukan upaya-upaya untuk memperbaiki kondisi alam di wilayah Ogan Ilir, komunitas ini melakukan aksi penanaman pohon guna menjaga kelestarian alam dalam jangka panjang sekaligus sebagai upaya untuk menggantikan tumbuhan yang terbakar pada saat musim kemarau.

Ketika lahan yang terbakar dapat ditanggulangi dengan cepat maka bencana tersebut tidak akan menimbulkan dampak negatif yang terlalu besar bagi wilayah Ogan Ilir. Kepala Staf Pencegahan dan Kesiapsiagaan BPBD Ogan Ilir mengemukakan :

“...wilayah di Ogan Ilir ini sebagian besar yang berupa rawa, hutan, dan semak belukar memang sangat rentan tebakar pada saat musim kemarau. Selain karena memang sengaja dilakukan pembakaran oleh masyarakat yang membuka lahan, dan juga memang rendahnya kesadaran dari masyarakat untuk membuka lahan dengan cara yang lebih ramah lingkungan. Kondisi geografis juga sangat mendukung terjadinya bencana kebakaran lahan, terutama pada lahan gambut yang jika terkena puntung rokok saja sudah bisa menimbulkan kebakaran lahan yang dahsyat, terutama saat bersamaan dengan angin yang cukup kencang maka sudah dapat dipastikan kebakaran akan membesar dan menyebar pada lahan yang luas" (Wawancara dengan Pipit Oktarina, 23 Januari 2018).

Para pemuda memahami bahwa aspek geografis dari Kabupaten Ogan Ilir memiliki kerentanan terhadap bencana kebakaran hutan dan lahan, sehingga sangat penting untuk memiliki kesadaran dan lebih peduli terhadap lingkungannya. Peran pemuda dalam penanggulangan bencana kebakaran lahan bersama-sama dengan BPBD Ogan Ilir dapat meningkatkan kemampuan dalam memadamkan kebakaran dan meminimalisir dampak yang terjadi sehingga memperkuat ketahanan wilayah Ogan Ilir.

\section{Aspek Sumber Daya Alam}

Bencana kebakaran hutan dan lahan dapat mengganggu ekosistem biotik dan abiotik yang sudah pasti akan berdampak pada tidak maksimalnya pengelolaan terhadap sumber daya alam. Pengelolaan kekayaan sumber daya alam bertujuan untuk memperoleh manfaat yang sebesar-besarnya dari potensi yang telah disediakan oleh alam. Kabupaten Ogan Ilir merupakan daerah yang memiliki hasil pertanian cukup baik dan sebagai sumber pendapatan daerah terbesar hingga saat ini. Terdapat perusahaanperusahaan perkebunan yang cukup besar yakni perkebunan kelapa sawit, tebu, dan juga karet. Selain itu budidaya ikan air tawar juga mejadi sektor yang menjanjikan, dan terbukti mengalami peningkatan setiap tahunnya serta memberikan keuntungan bagi masyarakat.

Kondisi wilayah yang rentan terhadap bencana kebakaran lahan harus diimbangi dengan upaya pencegahan dan penanggulangan bencana kebakaran hutan dan lahan guna menjaga sumber daya alam yang ada di Ogan 
Ilir. Seperti halnya yang dikemukakan oleh Ayu Lestari :

“...sebenarnya kepedulian kami ini antara lain untuk menjaga sumber daya alam di Ogan Ilir yang terancam jika terus dibiarkan. Kasihan para petani jika lahannya terbakar sedangkan itu menjadi penghasilan utama bagi mereka, terutama yang diwilayah perkebunan, kalau di wilayah rawa kami lebih kepada menjaga vegetasi dan kondisi alam sekitarnya karena memang tidak digunakan untuk bertani" (Wawancara dengan Ayu Lestari, 17 Januari 2018)

Ketika terjadi bencana kebakaran hutan dan lahan maka semua aspek sumber daya alam yang berada di wilayah rawan terbakar terancam keberadaannya. Lahan pertanian yang dikelola oleh masyarakat sangat rentan terbakar, begitu pula perkebunan-perkebunan yang dikelola oleh perusahaan. Sedangkan dampak lain ketika terjadi kebakaran hutan dan lahan maka akan diirngi oleh meningkatnya suhu udara yang berakibat buruk bagi sumber daya alam yang ada. Kehadiran komunitas Elite Arari cukup membantu untuk mencegah meluasnya bencana kebakaran sehingga wilayah lahan pertanian mampu diselamatkan, selain itu kekayaan sumber daya alam daerah juga lebih terjaga.

\section{Aspek Demografi}

Aspek demografi atau kependudukan merupakan aspek yang berkaitan dengan daya dukung dari segi geografis, dan membahas hal-hal terkait laju pertumbuhan penduduk, komposisi penduduk, rasio ketergantungan, migrasi, kepadatan, persebaran penduduk dan lain sebagainya. Kondisi geografis dari suatu wilayah mempengaruhi laju pertumbuhan penduduk suatu wilayah, kondisi geografis juga sangat menentukan tingkat pendapatan dan kesejahteraan masyarakat dalam suatu wilayah.

Komposisi penduduk di wilayah Ogan Ilir tersebar dalam 16 kecamatan dapat menjadi bekal utama dalam upaya pencegahan dan penanggulangan bencana dalam jangka panjang, pemerintah tidak akan pernah berhasil mencegah terjadinya bencana kebakaran lahan di tahun-tahun berikutnya jika tidak didukung oleh kesadaran dari masyarakat untuk tidak melakukan pembakaran terhadap hutan dan lahan. Dibutuhkan kerjasama antara seluruh lapisan masyarakat untuk dapat menanggulangi bencana ini, masyarakat menjadi modal utama yang akan sangat memberikan dampak signifikan bagi ketahanan wilayah ketika dapat diberdayakan secara masksimal.

Para anggota komunitas Elite Arari memiliki rasa tanggung jawab karena menjadi bagian dari masyarakat yang mendiami wilayah Ogan Ilir sehingga berupaya untuk turut meningkatkan ketahanan wilayah dengan membantu pihak pemerintah dalam mencegah dan menanggulangi bencana kebakaran hutan dan lahan. Seperti yang dikemukakan oleh salah satu satgas BPBD Ogan Ilir Yudha Pratama :

"Penyebab utama terjadinya kebakaran
hutan dan lahan setiap tahun adalah
masyarakat yang masih belum memiliki
kesadaran untuk tidak membuka lahan
dengan menggunakan api, walaupun sudah
terdapat peraturan yang dibuat dan juga
dilakukan sosialisasi tetapi tetap saja
masyarakat enggan untuk meninggalkan
cara lama dan tetap melakukannya kembali.
Jika api sudah meluas barulah masyarakat
kebingungan dan meminta bantuan kami
untuk memadamkan api. Jadi memang
masyarakatlah yang menjadi kunci utama
untuk mencegah kebakaran" (Wawancara
dengan Yudha Pratama, 23 Januari 2018). 
Sundari Utami, Armaidy Armawi, Danang Sri Hadmoko -- Implikasi Peran Pemuda Dalam Penanggulangan Bencana Kebakaran Hutan Dan Lahan Terhadap Ketahanan Wilayah (Studi Pada Pemuda Komunitas Elite Armada Rimba Sriwijaya, Kabupaten Ogan Ilir, Sumatra Selatan)

Pemuda sebagai penduduk dengan kelompok umur tertentu dikenal memiliki semangat yang tinggi untuk mewujudkan apa yang dicita-citakan, begitu pula dengan anggota Komunitas Elite Arari yang memiliki kepedulian untuk menjaga dan melestarikan lingkungan di Ogan Ilir.

\section{Aspek Ideologi}

Terjadinya bencana alam kebakaran hutan dan lahan tentu saja dapat berpengaruh pada aspek ideologi suatu negara, dengan terjadinya bencana yang terus-menerus maka akan terjadi gejolak dari masyarakat yang tidak puas atas kinerja pemerintah yang telah mereka beri kepercayaan sepenuhnya untuk mengatur kehidupan berbangsa dan bernegara.

Negara dapat dijadikan kambing hitam atas terjadinya serangkaian bencana di setiap tahunnya yang bahkan berimbas pada negara lain. Ketahanan dari suatu wilayah sangat dibutuhkan guna menjaga kekuatan ideologi yang dianut oleh negara ini, nilai-nilai yang terkandung dalam Pancasila hendaknya dijadikan dasar bagi pemerintah masyarakat untuk mencapai apa yang menjadi tujuan dari dasar negara.

Upaya untuk menjaga ideologi negara dapat dilakukan dengan cara meningkatkan keuletan dan ketangguhan masyarakat dalam mengahadapi bencana kebakaran hutan dan lahan yang terjadi di Kabupaten Ogan Ilir. Komunitas Elite Arari telah berupaya untuk meningkatkan kesadaran dan pemahaman dari masyarakat untuk bersama-sama turut menanngulangi bencana kebakaran hutan dan lahan, hal tersebut sebagai bentuk salah satu upaya yang dilakukan dalam rangka menjalankan amanat dari Pancasila sebagai ideologi negara yang menjadi landasan hidup bagi bangsa Indonesia. Sebagaimana yang dikemukakan oleh ketua Komunitas Elite Arari Ayu Lestari :

“Kami merasa harus bertanggung jawab
terhadap terhadap lingkungan kami terutama
di wilayah Ogan Ilir, karena mungkin untuk
saat ini hanya hal itu yang mampu kami
lakukan sebagai bentuk rasa cinta kami
terhadap NKRI. Kami tidak mengharapkan
imbalan, kami hanya meminta dukunganagar
kami bersama-sama dengan masyarakat
mempu memperbaiki kondisi lingkungan di
wilayah agar dikemudian hari dapat tercipta
kehidupanyang asri, tenang, aman, adil, dan
sejahtera sebagaimana yang diharapkan
oleh bangsa ini’(Wawancara dengan Ayu
Lestari, 17 Januari 2018).

Pelaksanaan nilai-nilai Pancasila menjadi modal utama dalam menghadapi beragam ancaman, tantangan, dan hambatan yang terjadi. Hal tersebut yang telah dilakukan oleh Komuntas Elite Arari untuk berperan dalam penanggulangan bencana sebagai bentuk kepedulian terhadap tanah air dengan mengamalkan nilai-nilai yang terkandung di dalam Pancasila sebagai ideologi negara Indonesia.

\section{Aspek Politik}

Kondisi stabillitas politik menjadi salah satu faktor hadirnya kebijakan yang sesuai dengan kebutuhan masyarakat dengan berlandaskan nilai-nilai Pancasila, kondisi politik yang sehat dapat dilihat dari keselarasan hubungan antara pemerintah sebagai pemangku kekuasaan dengan masyarakat sebagai pemberi kepercayaan. Dalam mewujudkan ketahanan nasional suatu negara maka dibutuhkan ketahanan politik, mengingat politik menjadi aspek terpenting yang menentukan pihak mana yang akan berkuasa, bagaimana input yang dihasilkan, dan seberapa efektif hasil yang didapatkan. 
Aspek politik dalam kehidupan masyarakat di suatu wilayah senantiasa mendapatkan ancaman, gangguan, dan hambatan yang berasal dari dalam maupun dari luar. Bencana hadir menjadi salah satu yang dapat mengganggu kestabilan situasi politik suatu wilayah, karena bencana merupakan permasalahan yang dampak dan kerugiannya dirasakan langsung oleh masyarakat. Sedangkan masyarakat merasa telah memberikan kepercayaannya kepada pemerintah sebagai pemangku kebijakan untuk dapat mencegah dan menanggulangi bencana yang terjadi tanpa memperdulikan penyebab dan terjadinya bencana tersebut.

Bencana karhutla jika tidak ditanggulangi dengan tepat maka akan menimbulkan rasa ketidakpercayaan masyarakat kepada pemerintahan yang berakibat pada gejolak politik dalam kehidupan masyarakat, selain itu dampak kabut asap yang ditimbulkan dapat mencapai negara-negara tetangga yang berada tidak jauh dari batas negara Indonesia seperti Malaysia, Singapura, dan juga Brunei. Hal tersebut mengakibatkan terganggunya hubungan diplomasi antar negara karena bencana kebakaran lahan yang terjadi di Indonesia juga menimbulkan kerugian berupa polusi dan kabut asap bagi negara tetangga. Sebagaimana yang dikemukakan oleh Muhammad Alghifari :

“...kami sebenarnya juga berusaha untuk menetralisir ketegangan antara masyarakat dan pihak pemerintah. Sebagaian masyarakat merasa tidak puas atas kinerja pemerintah dalam menanggulangi kebakaran lahan, padahal sudah jelas pemerintah juga tidak akan mampu menanggulangi bencana itu tanpa adanya peran serta dari masyarakat. Selain itu demonstarasi yang terjadi di berbagai daerah juga semakin memperparah keadaan, memang benar jika pemerintah jugaharus di ingatkan tetapi juga alangkah lebih baiknya jika para pemuda bersamasama turun ke lapangan dengan aksi yang nyata membantu pemerintah memadamkan kebakaran. Jika demikian tentu kondisinya akan lebih kondusif" (Wawancara dengan Muhammad Alghifari, 30 Januari 2018)

Peran pemuda Komunitas Elite Arari dalam menanggulangi bencana kebakaran hutan dan lahan berimplikasi baik pada aspek politik di Kabupaten Ogan Ilir. Para pemuda anggota komunitas tersebut telah berupaya maksimal sesuai dengan kemampuannya untuk turut menjaga dan membantu menciptakan situasi politik yang kondusif.

\section{Aspek Ekonomi}

Roda perekonomian di Ogan Ilir dipengaruhi oleh aktivitas pertanian dan juga perdagangan yang mata pencaharian utama bagi masyarakat. Dalam prosesnya, ketika terjadi bencana kebakaran hutan dan lahan dengan skala yang besar mengakibatkan terganggunya aktivitas perekonomian dikarenaka dampak buruk bencana berupa meningkatnya suhu udara dan memburuknya kualitas udara. Kegiatan yang dilakukan oleh Komunitas Elite Arari untuk mencegah dan menanggulangi bencana kebakaran lahan di Ogan Ilir dengan melakukan sosialisasi di sekolah-sekolah, serta kampanya lingkungan hidup bertujuan agar ke depannya bencana serupa tidak terjadi lagi sehingga kegiatan perekonomian dapat berjalan dengan sebagaimana mestinya tanpa terganggu oleh adanya bencana kebakaran hutan dan lahan.

Peran para pemuda dari Komunitas Elite Arari yang turut serta dalam menanggulangi bencana kebakaran hutan lahan juga merupakan upaya untuk menyelamatkan lingkungan sekaligus masyarakat dari 
Sundari Utami, Armaidy Armawi, Danang Sri Hadmoko -- Implikasi Peran Pemuda Dalam Penanggulangan Bencana Kebakaran Hutan Dan Lahan Terhadap Ketahanan Wilayah (Studi Pada Pemuda Komunitas Elite Armada Rimba Sriwijaya, Kabupaten Ogan Ilir, Sumatra Selatan)

dampak buruk yang ditimbulkan. Saat terjadi kebakaran lahan dan menimbulkan kabut asap maka masyarakat dan para mahasiswa enggan untuk keluar rumah untuk sekedar membeli kebutuhan sehari-hari, hal ini dialami langsung oleh peneliti yang sempat merasakan dampak kebakaran lahan berupa kabut asap pekat yang mengganggu jarak pandang dan kesehatan. Sebagaimana yang dikemukakan oleh anggota satgas BPBD Ogan Ilir yang bernama Mugif Buansyah :

“...jika bencana kebakaran terjadi dalam wilayah yang luas maka akan menimbulkan asap dan polusi yang mengganggu aktifitas masyarakat. Biasanya pasar menjadi sepi, pedagang sepi, kampus dan sekolah diliburkan, bahkan bandara juga sering mengalami penutupan sementara ketika kondisi udara benar-benar parah. Kebanyakan masyarakat untuk sekedar ke warung untuk membeli kebutuhan saja masih enggan karena buruknya kondisi cuaca saat bencana. Dalam kondisi seperti itu kami harus terus berusaha untuk dapat memadamkan api sehingga keadaan dapat segera pulih dan berjalan normal seperti biasa" (Wawancara dengan Mugif Buansyah, 23 Januari 2018).

Peran para pemuda dari Komuntas Elite Arari dalam penanggulangan bencana kebakaran hutan dan lahan di wilayah Kabupaten Ogan Ilir berimplikasi baik dalam menjaga kestabilan kondisi ekonomi di wilayah tersebut, meskipun belum berjalan maksimal tapi sudah ada upayaupya yang dilakukan oleh komuntas tersebut sebagai upaya untuk menjaga dan memulihkan kondisi kegiatan perekonomian yang terganggu pada saat bencana. Dengan demikian komunitas Elite Arari memiliki pengaruh cukup baik terhadap aspek ekonomi di wilayah Ogan Ilir.

\section{Aspek Sosial Budaya}

Kondisi sosial budaya di Kabupaten Ogan Ilir tersusun atas beragam suku dan budaya, yang menjunjung nilai-nilai toleransi dan gotong royong antar sesama. Namun tidak jarang terjadi konflik sosial ketika terjadi kebakaran lahan yang disebabkan oleh salah satu masyarakat yang membuka lahan dengan menggunakan api tetapi tidak mampu mengendalikannya sehingga api menyebar dan menjalar membakar lahan milik orang lain, ketika hal tersebut terjadi maka dapat dipastikan akan terjadi konflik antara anggota masyarakat. Begitu pula ketika perusahaan membuka lahan dengan menggunakan api dengan memerintahkan orang lain untuk membakar dan kemudian api tidak dapat dikendalikan dan menjalar ke lahan milik masyarakat maka akan menimbulkan konflik antara masyarakat dengan pihak perusahaan.

Rasa sentimentil terhadap pihak perusahaan sering menjadi pemicu konflik dikemudian hari karena adanya rasa tidak puas dari masyarakat dengan hadirnya perusahaan perkebunan di wilayah mereka. Sebagaimana yang dikemukakan oleh Muhamad Aminudin :

“...masyarakat menjadi lebih sensitif kepada pihak perusahaan karena dianggap menyebabkan kebakaran lahan, perusahaan perkebunan yang membuka lahan dengan cara dibakar meskipun telah menyiapkan petugas pemadaman tetap saja dianggap menjadi salah satu pemicu terjadinya kebakaran yang luas. Selain itu juga sering ketika ada warga yaNg membuka lahan miliknya dengan cara dibakar tetapi kemudian api membesar dan merambat ke lahan milik orang lain, hal seperti itu seringkali menimbulkan masalah dan rasa saling tidak suka antara satu dengan yang lain. Hal seperti ini yang harus 
dihindari karena sangat mengganggu kehidupan sosial masyarakat di Ogan Ilir, kamipun masih terus berusaha untuk mencegah dan meminimalsir terjadinya hal yang demikian dengan membantu pihak pemerintah memadamkan kebakaran" (Wawancara dengan Muhamad Aminudin, 17 Januari 2018).

Upaya yang telah dilakukan oleh komunitas Elite Arari dalam menanggulangi bencana berimplikasi pada stabilnya kondisi sosial dari masyarakat, meskipun masih belum maksimal karena keterbatasan. Namun sudah ada upaya yang masih terus dilakukan sampai dengan saat ini untuk menanggulangi bencana di Ogan Ilir demi menciptakan suasana kodusif.

\section{Aspek Keamanan Wilayah}

Keamanan wilayah merupakan kondisi dari suatu wilayah yang memiliki kekuatan untuk menciptakan kondisi yong kondusif tanpa adanya gejolak sehingga masyarakat dapat hidup dengan tenang tanpa adanya gangguan dan ancaman. Keamanan wilayah dapat diwujudkan dengan memanfaatkan potensi yang dimiliki oleh suatu wilayah termasuk kekuatan masyarakat untuk menghadapi ancaman dan hambatan yang hadir sehingga tidak sampai mengganggu stabilitas kondisi suatu wilayah.

Bencana kebakaran hutan dan lahan di Kabupaten Ogan Ilir seharusnya dihadapi dengan kesiapsiagaan dari berbagai pihak tidak hanya pemerintah tetapi juga dari masyarakat untuk melindungi wilayahnya dari gangguan berupa kebakaran lahan. Untuk saat ini memang sebagian masyarakat enggan turut serta dalam upaya pencegahan dan penanggulangan bencana kebakaran lahan, namun di sisi lain masih terdapat para pemuda yang bersedia membantu petugas BPBD Ogan Ilir dalam menanggulangi kebakaran hutan dan lahan yang terjadi.

Penanggulangan bencana kebakaran hutan dan lahan secara cepat dan tepat berimplikasi baik terhadap terwujudnya keamanan suatu wilayah sehingga dapat tercipta kondisi yang aman pada saat terjadi bencana. Penanggulangan yang dilakukan juga menimbulkan ketenangan bagi masyarakat sehinga berdampak baik pada kehidupan masyarakat. Biasanya pada saat kebakaran lahan masyarakat menjadi panik karena takut jika lahannya akan terbakar, selain itu adanya jalur pipa gas bertekanan tinggi juga menjadi ancaman tersendiri ketika terjadi kebakaran karena akan sangat berbahaya jika terjadi ledakan. Sebagaimana yang dikemukakan oleh Dedi Kurniawan :

“...kami menanggulangi kebakaran dampaknya bukan hanya api yang padam saja, tetapi juga menenangkan masyarakat pada saat terjadi kebakaran lahan. Bagi masyarakat yang daerahnya cukup jauh, mereka sangat khawatir jika api terus membesar dan membakar lahan milik mereka bahkan untuk titik api yangdekat dengan pemukiman mereka sangat takut jika api akan menjalar ke rumah-rumah mereka, selain itu adanya pipa aliran gas bertekanan tinggi juga akan sangat berbahaya jika terkena suhu panas yang tinggi sehingga hal itu menjadi daerah prioritas bagi BPBD untuk dipadamkan. Kami yang biasanya memadamkan api di daerah benar-benar melihat bagaimana paniknya masyarakat yang kebun atau lahannya terbakar, kami bebrusaha semaksimal mungkin untuk memadamkan agar masyarakat tidak merugi" (Wawancara dengan Dedi Kurniawan, 17 Januari 2018) 
Sundari Utami, Armaidy Armawi, Danang Sri Hadmoko -- Implikasi Peran Pemuda Dalam Penanggulangan Bencana Kebakaran Hutan Dan Lahan Terhadap Ketahanan Wilayah (Studi Pada Pemuda Komunitas Elite Armada Rimba Sriwijaya, Kabupaten Ogan Ilir, Sumatra Selatan)

Tabel 1

Implikasi Peran Pemuda Komunitas Elite Arari dalam Penanggulangan Bencana Kebakaran Hutan dan Lahan Terhadap Ketahanan Wilayah Kabupaten Ogan Ilir Provinsi Sumatera Selatan

\begin{tabular}{|c|c|c|}
\hline No & $\begin{array}{c}\text { Aspek Ketahanan } \\
\text { Wilayah }\end{array}$ & Implikasi \\
\hline 1. & Geografis & $\begin{array}{l}\text { - Mencegah peningkatan suhu dan pencemaran udara } \\
\text { - Dampak polusi kabut asap dapat diminimalisir } \\
\text { - Terjaganya unsur biotik dan abiotik } \\
\text { - Lalu lintas darat dan udara tidak mengalami hambatan }\end{array}$ \\
\hline 2. & $\begin{array}{c}\text { Sumber Daya } \\
\text { Alam }\end{array}$ & $\begin{array}{l}\text { - Terjaganya kekayaan SDA } \\
\text { - Daerah pertanian mampu diselamatkan dari kebakaran } \\
\text { - Keberadaan SDA dapat memberi hasil maksimal }\end{array}$ \\
\hline 3. & Demografi & $\begin{array}{l}\text { - Penduduk dengan kategori usia muda dapat lebih diberdayakan guna } \\
\text { penanggulangan bencana karhutla } \\
\text { - Penduduk di wilayah tersebut menjadi termotivasi untuk turut serta menanggulangi } \\
\text { bencana karhutla }\end{array}$ \\
\hline 4. & Ideologi & $\begin{array}{l}\text { - Menumbuhkan rasa cinta pada tanah air } \\
\text { - Terjaganya ideologi negara dengan adanya kepercayaan dari masyarakat }\end{array}$ \\
\hline 5. & Politik & $\begin{array}{l}\text { - Masyarakat menjadi lebih tenang dan mempercayai pihak pemerintah Masyarakat } \\
\text { - Tenjadi lebih tenang dan mempercayai pihak pemerintah } \\
\text { - Terjaganya hubungan diplomatik antar negara }\end{array}$ \\
\hline 6. & Ekonomi & $\begin{array}{l}\text { - Meminimalisir dampak kabut asap bagi aktivitas masyarakat dalam memenuhi } \\
\text { - Kebutuhan } \\
\text { - Kondusifnya kegiatan perekonomian di pasar-pasar } \\
\text { - Tidak terganggunya kegiatan ekonomi sektor transportasi } \\
\text { - Masyarakat dapat bekerja dengan tenang }\end{array}$ \\
\hline 7. & Sosial Budaya & $\begin{array}{l}\text { - Terjaganya hubungan sosial antar masyarakat, masyarakat dengan perusahaan, dan } \\
\text { masyarakat dengan pemerintah } \\
\text { - Mencegah terjadinya konflik vertikal dan horizontal }\end{array}$ \\
\hline 8 & $\begin{array}{l}\text { Keamanan } \\
\text { Wilayah }\end{array}$ & $\begin{array}{l}\text { - Terciptanya rasa aman dan tenang dalam kehidupan masyarakat } \\
\text { - Masyarakat tidak mudah terpancing emosi } \\
\text { - Terciptanya suasana yang kondusif }\end{array}$ \\
\hline
\end{tabular}

Sumber : Olahan Peneliti, 2018

Peran para pemuda Komunitas Elite Arari dalam menanggulangi bencana kebakaran hutan dan lahan dilakukan dengan senantiasa menjalin koordinasi dengan pihak pemerintah berwenang yakni BPBD, TNI, dan POLRI agar dapat menanggulangi bencana kebakaran lahan secara tepat dan cepat dan memberikan dampak positif bagi masyarakat Ogan Ilir dalam rangka menciptakan keamanan bagi masyarakat.

Ketahanan wilayah dapat dilihat melalui implikasi peran pemuda Komunitas Elite Arari pada aspek-aspek Astagatra. Dari hasil analisis yang telah dilakukan menunjukkan bahwa terdapat peranan yang dilakukan oleh para pemuda pada penanggulangan bencana kebakaran hutan dan lahan, terutama pada tahap pra bencana dan saat bencana. Peran tersebut berimplikasi pada ketahanan wilayah di Kabupaten Ogan Ilir (tabel 1).

\section{SIMPULAN}

Berdasarkan hasil penelitian yang telah dideskripsikan di atas dapat ditarik simpulan sebagai berikut.

Pertama, pemuda anggota Komunitas Elite Arari telah berperan aktif dalam upaya penanggulangan bencana kebakaran 
hutan dan lahan di Kabupaten Ogan Ilir. Kegiatan pada pra bencana kebakaran lahan dilakukan dengan mengadakan kegiatan sosialisasi terhadap pelajar dan pembinaan terhadap diri, sesama, dan lingkungan. Sedangkan peranan pada tahap saat bencana atau tanggap darurat dilakukan dalam bentuk pemantauan dan komunikasi serta pemadaman kebakaran hutan dan lahan. Sedangkan pada tahap pasca bencana Komunitas Elite Arari tidak menjalankan perannya dan menyerahkan sepenuhnya pada pihak pemerintah daerah. Dari ketiga tahap kegiatan penanggulangan tersebut, peran pemuda Komunitas Elite Arari yang paling berpengaruh dalam penanggulangan bencana dan ketahanan wilayah Ogan Ilir adalah kegiatan pemadaman kebakaran hutan dan lahan pada fase saat bencana atautanggap darurat.

Kedua, peran dari Komunitas Elite Arari dalam menanggulangi bencana kebakaran hutan dan lahan berimplikasi pada seluruh aspek kehidupan masyarakat seperti pada aspek geografi mampu menumbuhkan kesadaran dan kepedulian terhadap lingkungan, pada aspek demografi dengan merubah pola pikir masyarakat untuk menyadari bahwa masyarakat juga harus berperan untuk menanggulangi bencana kebakaran lahan yang terjadi, menciptakan kondisi situasi politik yang kondusif, mewujudkan kesejahteraan masyarakat melalui kegiatan perekonomian yang kondusif, menjaga kondisi sosial masyarakat agat tidak terjadi konflik vertikal dan horizontal, serta dengan menciptakan keamanan dan ketertiban di wilayah Ogan Ilir. Implikasi yang paling signifikan ada pada aspek geografis dan juga pasa aspek ekonomi.

\section{DAFTAR PUSTAKA}

Alfaqi, M, Habibi, M \& Rapita, D 2017, “Peran Pemuda Dalam Upaya Pencegahan Korupsi dan Implikasinya Terhadap Ketahanan Wilayah”, dalam Jurnal Ketahanan Nasional, Vol. 23 No. 3 edisi Desember 2017, Hal 320-337

BIOCLIME., 2015, Laporan dan Modul

Teknis Pemutakhiran Peta Kebakaran Hutan dan Lahan di Provinsi Sumatera SelatanTahun 2015. Sumatera Selatan : GIZ BIOCLIME Project.

BPS Kabupaten Ogan Ilir, 2017, Ogan Ilir Dalam Angka 2017, Ogan Ilir, BPS Kabupaten Ogan Ilir.

Glover, David. dan Jessup, Timothy., 2002, Mahalnya Harga Sebuah Bencana: Kerugian Lingkungan Akibat Kebakaran dan Asap di Indonesia, Bandung: ITB

Kollek, Daniel, 2013, Disaster Preparedness for Health Care Facilities, USA: McMaster University.

Lemhannas., 1997, Ketahanan Nasional., Jakarta: Balai Pustaka.

Pradikta, M, Giyarsih, S \& Hartono 2018, "Peran Pemuda Dalam Pengurangan Risiko Bencana Dan Implikasinya Terhadap Ketahanan Wilayah Desa Kepuharjo, Kecamatan Cangkringan, Kabupaten Sleman, Daerah Istimewa Yogyakarta” dalam Jurnal Ketahanan Nasional, Vol. 24 No 2 edisi Agustus 2018, Hal 261-286

Soekanto, Soerjono, 2015, Sosiologi Suatu Pengantar, Jakarta: Raja Grafindo Persada.

The World Bank., 2016, Kerugian Dari Kebakaran Hutan, Jakarta: Bank Dunia. Triutomo, Sugeng., 2013, Rencana Kontinjensi Nasional Menghadapi 
Sundari Utami, Armaidy Armawi, Danang Sri Hadmoko -- Implikasi Peran Pemuda Dalam Penanggulangan Bencana Kebakaran Hutan Dan Lahan Terhadap Ketahanan Wilayah (Studi Pada Pemuda Komunitas Elite Armada Rimba Sriwijaya, Kabupaten Ogan Ilir, Sumatra Selatan)

Ancaman Bencana Asap Akibat Peraturan Pemerintah No. 21 Tahun

Kebakaran Hutan dan Lahan, Jakarta: BNPB. 2008 Tentang Penyelenggaraan Penanggulangan Bencana

Utami, Sundari, 2018, Peran Pemuda Dalam Penanggulangan Bencana Kebakaran Hutan dan Lahan Serta Implikasinya Terhadap Ketahanan Wilayah (Studi Pada Kumunitas Pecinta Alam Elite Armada Rimba Sriwijaya di Kabupaten Ogan Ilir Provinsi Sumatera Selatan), Tesis, Program Studi Ketahanan Nasional Sekolah Pascasarjana Universitas Gadjah Mada, Yogyakarta

\section{Peraturan Perundangan}

Undang-Undang No. 24 Tahun 2007 Tentang Penanggulangan Bencana

Undang-Undang No. 40 Tahun 2009 Tentang Kepemudaan

Permen Lingkungan Hidup No. 32 Tahun 2016 Tentang Pengendalian Kebakaran Hutan dan Lahan

\section{Wawancara}

1. Ayu Lestari (Ketua Komunitas Elite Arari)

2. Dedi Kurniawan (Anggota Komunitas Elite Arari)

3. Muhammad Aminudin (Anggota Komunitas Elite Arari)

4. Muhammad Alghifari (Angota Komunitas Elite Arari)

5. Pipit Oktarina (Kasi Siap Kesiagaan BPBD Ogan Ilir)

6. Yudha Ilham (Satgas BPBD)

7. Mugif Buansyah (Satgas BPBD) 